\title{
GEOGRAPHICAL PATTERNS OF PARTY SUPPORT IN THE BALTIC STATES, RUSSIA, AND UKRAINE
}

\section{Andrey Meleshevich}

National University of Kyiv-Mohyla Academy, Kyiv, Ukraine

\begin{abstract}
This article analyses spatial patterns of party support in the five post-Soviet transitional countries: Estonia, Latvia, Lithuania, Russia, and Ukraine. Data on electoral geography is employed to measure the degrees and dynamics of political autonomy and institutionalization of party systems in the former republics of the Soviet Union. A comparison of post-independence electoral cycles reveals a number of important similarities and differences between the regional strength of party support in the Baltic states, Russia, and Ukraine over time. Although all five countries manifest a tendency towards a greater regional homogeneity of the regional support for the major political organizations, the pace of this trend and patterns of party-system nationalization are different in different countries.
\end{abstract}

KEY WORDS: geographical patterns of party support, political institutionalization, nationalization of party systems, political parties, party systems in Eastern Europe.

\section{Political institutionalization and autonomy of a party system}

The global movement to democracy in the past three decades has contributed to the renewed academic interest in political-institutionalization research. Political parties and party systems have become the primary focus of the contemporary institutional analysis of new democracies (e.g. Dix, 1992; Lewis, 1994; Jin, 1995; Mainwaring and Scully, 1995; McGuire, 1997; Levitsky, 1998; Bielasiak, 2002; Randall and Sväsand, 2002; van Biezen, 2003). This heightened interest in political parties among scholars is not surprising. A rare consensus among the overwhelming majority of political scientists holds that an institutionalized system of political parties is a necessary, though not sufficient, component of a successful democratic transition and consolidation. Larry Diamond and Juan J. Linz in their project Democracy in Developing Countries: Latin America found empirical support for this argument:

. . . the historical evidence from our own cases suggests that the crucial consideration for democracy is ... the degree of party institutionalization. All of our cases call attention to the institutional strength or weakness of parties as a determinant of success or failure with democracy, and each of them grapples with the problem of institutionalization. (Diamond and Linz, 1989: 21)

A country with an institutionalized party system accepts 'parties and elections as the legitimate institutions that determine who governs' (Mainwaring and Scully, 1995: 1) as a result of free and fair competition for votes. In an advanced democratic political system, parties firmly occupy their principal social niche by providing politicians with an access to power in an open electoral contest. On the contrary, a weakly institutionalized party system corresponds to a lack of legitimacy of political parties and representative bodies, as well as low levels of political predictability and accountability.

A student of political institutionalization faces a serious challenge in deciding how to operationalize this concept. Social scientists have proposed a variety of operational dimensions of institutionalization: adaptability, complexity, autonomy, coherence (Huntington, 1965; 1968); boundary, complexity, universalistic rules of decision-making (Polsby, 1968); autonomy, differentiation, durability (Keohane, 1969); autonomy and systemness (Panebianco, 1988); systemness, autonomy, value infusion, reification (Randall and Sväsand, 2002), and so on. Although no two scholars have arrived at the same set of criteria for political institutionalization, a broad consensus in the literature seems to suggest that the study of institutionalization of a political organization or procedure requires at minimum a discussion of autonomy as one of the elements of this concept.

Autonomy as a dimension of institutionalization was originally proposed by Samuel Huntington (1965) in his pioneering article 'Political Development and Political Decoy'; and developed by other political scientists (Keohane, 1969; Welfling, 1973; Panebianco, 1988; Randall and Sväsand, 2002). Huntington defines autonomy as 'the extent to which political organizations and procedures exist independently of other social groupings and methods of behavior' (Huntington, 1968: 20). He continues: 
Political institutionalization, in the sense of autonomy, means the development of political organizations and procedures that are not simply expressions of the interests of particular social groups. A political organization that is the interest of a social group . . . lacks autonomy and institutionalization. (1968: 20)

In his study of the UN General Assembly, Robert Keohane argues that autonomy, which indicates the ability of the organization to withstand environmental pressures and make decisions independent from its environment, is 'the most important and complex of the three variables' that he has identified as components of institutionalization (Keohane, 1969: 866). According to Angelo Panebianco, 'institutionalization always involves at least some "autonomization" vis-à-vis the environment' (Panebianco, 1988: 55).

I agree with the authors who consider autonomy as a necessary element of institutionalization.1 A political institution should be functionally and structurally distinct from other political institutions and social groups. A highly autonomous organization or process should have an independent status and value of its own vis-a-vis its environment. The higher the degree to which an organization functions independently from its environment, the more highly institutionalized it is. Huntington is correct that an institutionalized political party should not serve simply as an instrument of a narrow political group. A party system consisting of organizations which draw their exclusive support from a certain social group or geographical region, and express interests of a particular social, national, or territorial segment of population, lacks autonomy and institutionalization across the entire country.

Although most scholars recognize that autonomy is an essential element of political institutionalization, a few question its usefulness. For example, Kenneth Janda argues: ' $[A]$ party can be highly institutionalized and yet lack independence of other groups (Huntington's autonomy) - as the Labour Party in Great Britain' (Janda, 1980: 19). However, recent developments in British party politics contradict Janda's argument. As a result of social changes in British society over the last few decades - i.e. the movement of the electorate towards the political centre and growth of the middle class - the Labour Party was unable to successfully compete with the Conservatives for four electoral cycles. This was partially a result of its excessive dependence on the Trade Unions. Tony Blair's 'Third Way' ideology, a textbook example of the Downsian spatial model of party competition, enhanced the autonomy of Labour by decreasing trade-union influence within the party and appealing to a broader stratum of British society.

Scholars conducting research on political institutionalization have offered numerous ways to measure the degree of autonomy of individual political parties and party systems: distinctiveness of organizational norms and values, control of party finances and material resources, presence of 'catchall' parties, selection patterns of party leaders, relations with its collateral associations, and so on. A useful way to operationalize autonomy is to investigate what role parties play in fulfilling social niches unique to this type of political organization. Thus, one of the most important functions of a party in a democratic setting is its participation in elections and the recruitment of political leaders into the legislative arena. Another distinctive mission of the party system is the political recruitment into the Cabinet. These two functional niches - electoral participation and Cabinet formation - belong to the 'exclusive domain' of parties (Katz, 1987: 5) and make them structurally distinct from other political institutions and social groups. The higher the degree to which the party system fulfils its unique missions and acts autonomously from other social institutions, the more highly institutionalized it is.

Although geographical patterns of voting and regional strength of party support may also serve as important and useful means to evaluate the degree of political institutionalization, electoral geography has been rarely employed to study comparative political parties. Many scholars argue that this is a significant shortcoming of party literature and call for a closer look at the 'territorial dimension' of electoral politics and geographical aspects of party competition (Hopkin, 2003: 227). A good indicator of autonomy of a political party is the level of its nationalization, or, in other words, the extent of homogeneity of its electoral support-base across the nation. As a rule, highly autonomous parties manifest a relatively equal share of the vote in different territorial constituencies. Weakly institutionalized parties draw their electoral strength from a significantly smaller territorial segment.

Kenneth Janda is among a few scholars in comparative politics who emphasized the significance of geographical voting statistics for a study of political parties. He developed the index of party's national orientation and differentiated between regionally oriented parties that 'choose not to compete seriously at the national level' and nationally oriented parties that 'compete with other parties across the country, and . .. [whose] success is rather uniform across regions' (Janda, 1980: 34). For party systems this argument can 
be modified as follows. As a rule, a party system is likely to possess a high level of political autonomy and institutionalization if its main elements (i.e. individual parties) have a relatively uniform electoral support across the entire territory of a country and express the interests of most, if not all, geographical parts of a nation. On the contrary, a party system would rate low in the autonomy dimension of institutionalization if it were dominated by political formations which are distinctly split according to regional lines, express narrow interests of some regions, and do not have a significant electoral base and influence in others.

One of the reasons why a spatial approach has not been widely used for the study of political institutionalization of parties and party systems is a lack of reliable regional electoral data necessary for a cross-national comparison. Scott Mainwaring and Timothy R. Scully acknowledge the value of political geography and explain their inability to use it in their investigation of party systems in Latin America: '[D]ata on electoral geography would be useful in showing how citizens perceive parties, measuring the strength of party support, and assessing voter stability in voters' electoral preferences ... Unfortunately we do not have sufficiently comparable data to undertake this effort here' (Mainwaring and Scully, 1995: 11). Although fewer than 10 years have passed since the publication of Mainwaring and Scully's work, data on electoral geography in newly democratizing countries has become more readily available, providing a researcher with additional opportunities to study these nations. For example, the Central Electoral Commissions of the five countries under study maintain informative websites which contain comparable electoral data with constituency breakdown, making it possible to conduct a crossnational analysis. The availability of the necessary electoral data allowed Mark P. Jones and Scott Mainwaring to conduct a study of the nationalization of party systems in 17 countries in the Americas, which according to the authors is the first attempt 'to provide empirical information about party system nationalization outside of the advanced industrial democracies' (Jones and Mainwaring, 2003: 158).

\section{Nationalization thesis}

The thesis of the nationalization of political parties in a modern society and its significance for democratic stability and survival is not new in political science. It is rooted in the politicaldevelopment approach, which 'has emphasized the integration of peripheral cultural identities and economic areas within broader national contexts' (Caramani, 2004: 4). Many scholars support the argument that nationalization of parties and voting patterns has a direct effect on the success of democratic consolidation: nationalization 'is a central element in the process of democratization' because it signifies the transition from a fragmented politics with strong local figures to 'national mechanisms of political accountability' (Caramani, 2004: 299).2 Other students of democratic transitions also emphasize the existence of political parties with uniform electoral support across space as an instrumental factor in consolidating and preserving democracy in countries with deep ethnic or national cleavages (Stepan, 2001; Jones and Mainwaring, 2003).

The political-science interpretation of the nationalization thesis was challenged by scholars in political geography. For example, John A. Agnew has for years questioned its significance. This leading political geographer recognizes that some 'aspects of the nationalization thesis are unimpeachable. The locus of political activity ... ha[s] expanded from the entirely local to the national . . . As a result, national political parties and national-scale institutions have assumed increased significance as mechanisms of political incorporation and expression at regional and local scales' (Agnew, 2002: 77). However, Agnew argues that the nationalization thesis is not necessarily supported by empirical evidence. In his study of Italian electoral developments, Agnew found that the nationalization argument in Italian political science is based largely upon intellectual foundations of this academic discipline independent of empirical demonstration (Agnew, 1988: 307). He strongly warns against a tendency to underestimate the role of the place and regional cleavages in political mobilization:

[T] he national state . . . is dependent on the political patterns that places construct. It is as much at their mercy as they are at the national state's. Political nationalization . . . is a historically contingent result of electoral choices made under the pressure of distinctive socialization processes in different places. (Agnew, 2002: 110)

The spatial variable should not be considered independently from historical influences and should be placed in a broader cultural context which has a great importance for geographical considerations (Agnew, 1990: 8). Reynolds (1990) and Lutz (1995) second Agnew 'that spatial factors can indeed have great effects 
on political behavior' (Lutz, 1995: 57). Hopkin illustrates how the organizational dynamics of a party may affect 'denationalization' of party politics (Hopkin, 2003).

At the heart of dispute between the two sides - political science and political geography - about the nationalization thesis is the disagreement regarding the extent of influence of regional and local factors on nationwide electorates and party systems. The political-science approach states that as votes for political parties homogenize across country districts the processes producing the uniform pattern are essentially national ones. On the contrary, political geography asserts that nationalizing vote patterns are the product of a combination of several factors including local, regional, and national ones.

National processes do not replace regional and local influences on the electorate. Recently, several empirical studies have tested the nationalization thesis. Daniele Caramani employed a number of quantitative techniques in his investigation of the dynamics of territorial homogeneity of party support in Western European countries. He convincingly demonstrated:

... a clear trend toward increasing nationally integrated electorates and homogeneous party systems over the past 150 years ... During the period of time covered, territorial differences in electoral behavior within countries constantly decreased, and parties cover an increased proportion of national territories with candidates and organizations . . . The empirical question of whether processes of territorial integration actually took place in Western Europe is therefore answered in the affirmative. (Caramani, 2004: 73-4)

Yet, in spite of the general trend towards homogenization of geographical support for political parties, a number of regional and cultural cleavages remain salient in European party politics (Caramani, 2004: 6).

The empirical evidence in the present study appears to support both Agnew's argument about the enduring importance of place in the era of national modernity and Caramani's finding about a clear trend towards greater homogeneity of party support in European countries. On the one hand, despite many years of a shared political past under communist rule which attempted to eliminate any major social cleavages, the five post-Soviet cases under study manifested significant regional variations in the strength of voting support for different political parties in all post-independence electoral cycles. Thus, the East-West geographical split in Ukraine is perhaps the most critical cleavage shaping the national political scene in this country. Since independence, two leading political forces - the Communist Party of Ukraine, and prodemocracy organizations (Rukh, Our Ukraine) - have never mastered more than 5 percent of the national vote in the most westerly and easterly oblasts of this country respectively (Table 5). Such profound differences have been caused by historical and cultural developments in these territories. The city of Kaunas and the region of Vilnius in Lithuania, Latgale in Latvia, Estonia's northeastern areas, two federal cities and North Caucasus in the Russian Federation, which consistently produce electoral outcomes considerably different from the rest of their countries, demonstrate that the place in conjunction with its historical context has been and will likely remain the primary predictor of their inhabitants' political identity (see Tables 1-4).

On the other hand, this article shows that all five former Soviet republics manifest a distinct trend towards a greater regional uniformity of the national party system and a more homogeneous pattern of voter support in all consequent post-1991 elections. Although the formation of the 'nationalized' party system does not totally replace regional and local influences, a tendency towards a greater homogeneity of party support across the country may have positive consequences for national unity by minimizing potentially destabilizing effects of regionally based political forces and indicating a greater commitment to national institutions. Numerous post-communist transitional countries (e.g. the former Yugoslavia, Georgia, Moldova) prove that these nations have been a long way from the consociational democratic model which explains political stability in several deeply divided Western European democracies through cooperation of regional elites. The destabilizing effects of geographical segmentation of political forces in new democracies might provoke an authoritarian response from the central authorities which impedes a movement of the country to democracy. The relationship between a territorial homogeneity of a national party system, social stability and democratic success or breakdown is a fascinating research question which requires further exploration. 


\section{Thesis and methodology}

The purpose of the present research is to measure the degree and dynamics of the geographical pattern of party support as an important dimension of party-system autonomy and institutionalization in the post-Soviet nations. Five countries - Estonia, Latvia, Lithuania, Russia, and Ukraine - have been selected for this study based on two criteria: the availability of electoral data sufficient for the purposes of the longitudinal analysis and reasonably free and fair parliamentary elections. For example, a lack of comparable voting statistics with constituency breakdowns for the 1994 and 1998 elections to the Moldovan national legislature prevented the inclusion of this country in my investigation. Belarus and most other former Soviet republics were excluded from the study as countries which do not correspond to the second criterion. Scholars who conduct multi-country geographical research often encounter a problem of finding comparable territorial units. An attempt to form comparable regional entities for a crossnational study brings another challenge - the socalled 'modifiable areal unit problem' when results of a spatial study may depend on the scale of the unit of aggregation (see Yule and Kendall, 1950; Openshaw and Taylor, 1979; Berglund, 1990). To avoid an arbitrary grouping of geographical units in this study, I follow either the established electoral or administrative divisions adopted by the five countries. Thus, Estonia and Latvia employ a proportional-representation electoral system in multiple electoral districts with the magnitudes ranging from 7 to 12 in Estonia and 14 to 26 in Latvia. I use 12 electoral constituencies (11 constituencies in the 1995 and 1999 elections) in Estonia and 5 voting districts in Latvia as areal units for my analysis. Three other countries - Lithuania, Russia, and Ukraine - conduct proportional representation elections in a single, multi-member, nationwide district. In these three cases, my spatial units are the largest administrativeterritorial divisions created by the national constitutions or other legislative acts. Lithuania presents 12 units (ten apskritys, or counties, and two cities of Vilnius and Kaunas); Russia has 89 administrative territorial entities (49 oblasts, 21 republics, 6 krais, 10 autonomous okrugs, 1 autonomous oblast, and 2 federal cities, namely Moscow and St Petersburg); and Ukraine has 27 administrative divisions (24 oblasts, the Crimean autonomous republic, and the cities of Kyiv and Sevastopil). For the reasons I explain below, the analysis of the party spatial support in the Russian Federation is presented in two alternative ways: (a) for all 89 administrative units; and (b) for 15 'super-regions'. I will analyse geographical patterns of voting to measure the regional strength of party support in the Baltic states, Russia, and Ukraine in all consecutive elections to the national legislatures since these countries achieved their independence in 1991. At the time when the present research was conducted, Estonia, Latvia, and Russia held four cycles and Lithuania and Ukraine three cycles of generally democratic elections for their national legislatures. To assess the dispersion of party strength across the nation I use the variability coefficient (CV), which is a simple and useful measure for describing variations in distributions.3 The CV measures a geographical dispersion of electoral support or, in other words, uniformity of the party's electoral strength across the entire territory of a nation. The variability coefficient of an electoral contestant is calculated according to the formula

$$
C V i, t=\frac{S i, t}{\mu i, t}
$$

where CVi,t stands for the variability coefficient of party $i$ at election $t, S$ is the standard deviation and $\mu$ is the mean value of shares of a district vote taken by a political party or electoral coalition throughout the country.

The standard deviation alone is not sufficient to study the regional strength of party support because it is biased towards larger electoral contenders, providing uneven analysis for parties that enjoy different levels of overall support. By dividing standard deviation by the mean value of the party vote one is able to compare the degree of variability in regional support for a political party or electoral coalition across country, regardless of its overall performance. Interpretation of this coefficient is fairly straightforward the higher the index, the lesser the degree of political autonomy of an electoral contestant because of its narrow regional base and appeal.

The $\mathrm{CV}$ is a handy measure for a comparison ofregional strength of individual political parties in the same nation. In addition, by calculating the average variability coefficient of major electoral contestants $(\mathrm{CV} \mu)$ per electoral cycle, one can also conduct multiple-country and multiple-election comparative studies. I have to strike a note of caution here. A longitudinal comparison of the party system within the same country and with the same number of areal entities by using $\mathrm{CV} \mu$ does not seem to present major methodological challenges. However, a cross-country investigation is more problematic: the variability 
coefficient is sensitive to changes in the quantity of units and biased towards a larger number of units. Since the larger number of constituencies under analysis produces a higher coefficient value, a comparison of 5 electoral districts in Latvia and 89 territorial units in the Russian Federation can be made only with certain reservations. $4 \mathrm{In}$ an attempt to present an alternative geographical scale and balance the manifestation of this bias, the Russian electoral data are reported in two ways: for all 89 regions and for 15 'super-regions' formed on the basis of geographical proximity and cultural similarities. Although the Russian 'super-regions' are different from the 12 electoral constituencies in Estonia in many ways, a relatively comparable number of units for all five case-studies provides an alternative approach for the use of the $\mathrm{CV} \mu$ in a cross-country investigation. A comparison of both scales side-byside allows us to draw a more consistent conclusion regarding the dynamics of political institutionalization in the Russian Federation and the other four nations. As Figure 1 demonstrates, both scales produce a similar tendency towards the nationalization of the Russian party system.

The reading of $\mathrm{CV} \mu$ is also straightforward - a country (or an electoral cycle) which is dominated by political formations divided according to territorial lines would manifest a higher CV value and a lower degree of political institutionalization in comparison to a nation (or an electoral cycle) where major political parties enjoy relatively even support throughout the country. Only parties which claimed at least 3 percent of the national vote in a given election are included in Tables 1-5. A selection of any other threshold - for example 2 percent or 4 percent of the vote - does not change the overall dynamics of regional strength of party support in the five countries.

\section{Discussion of results}

\section{Party systems}

Tables 1-5 and Figure 1 report geographical strength of party support in post-independence elections to the national legislatures in the Baltic states, Russia, and Ukraine.5 A comparison of the geographical patterns of voting clearly shows that party systems in all five nations demonstrate a distinct trend towards a more uniform dispersion of regional party support over time. The average variability coefficient $(\mathrm{CV} \mu)$ in the three Baltic states and Ukraine has been constantly decreasing in all postindependence electoral contests. Thus, in the founding elections, the $\mathrm{CV} \mu$ value in Lithuania, Estonia, Ukraine, and Latvia was $0.822,0.667,1.15$ and 0.476 respectively. The latest electoral cycle in these countries brought the variability coefficient down to $0.307,0.387,0.691$ and 0.314 which correspondingly constitutes a steady 63 percent, 43 percent, 40 percent, and 34 percent decrease. Beginning with the second competitive election, Russia also displays a movement towards a more uniform pattern of regional support for major political formations.6 However, this pattern is significantly weaker than in the other four countries. The $\mathrm{CV} \mu$ values in the second and the latest, fourth, cycles of post-independence elections in the Russian Federation were 0.58 and 0.485 (89 regions), and 0.409 and 0.364 ( 15 regions), or a 16 percent and 11 percent reduction respectively. The finding that all five former Soviet republics demonstrate a positive tendency towards more autonomous and institutionalized party systems is important, but not surprising. One might expect that a party system in a transitional country would become better entrenched in the society over time.

\section{Geographical cleavage}

Along with the overall tendency towards the nationalization of a political party system, all five countries feature a number of geographical regions that consistently produce electoral results noticeably different from the overall voting patterns in the nation. For example, in Latvia, electoral contestants who champion the rights of non-Latvians perform particularly well in the Latgale district populated predominantly by Russian-speaking Slavs. At the same time, such political organizations manifest a poor showing in the regions where Latvians constitute the larger share of voters, for example Kurzeme and Zemgale. Thus, Latgale awarded the Equal Rights coalition 15.65 percent of the constituency votes (in comparison, this electoral contender received 5.78 percent of the vote nationwide) in 1993; the Latvian Socialist Party 15.83 percent (5.58 percent of the national vote) in 1995; the National Harmony Party 35.84 percent (14.2 percent) in 1998; and For Human Rights in a United Latvia 36.8 percent (18.94 percent) in 2002. All these political formations promoted left-wing political and economic agendas, which led to the argument that the Russian-speaking population showed preference for the political left. Dzintra Bungs 
argues that '[i]n areas where non-Latvians constituted a large share of the voters, the left-ofcenter lists did well, conversely, in areas where Latvians composed the larger share of the electorate, there was a clear preference for the rightof-center lists' (Bungs, 1993).

Lithuania's Vilnius region, where ethnic Poles comprise a high proportion of its population, has overwhelmingly supported the Electoral Action of Lithuanian Poles in all post-independence elections. The city of Kaunas has provided disproportionate electoral support for right-wing nationalist political organizations in election after election.

In the Russian Federation, the most atypical regions which consistently yield electoral results different from those in the rest of the country are the two federal cities, Moscow and St Petersburg, as well as National Caucasus, which consists of several ethnic autonomous republics. Moscow and St Petersburg serve as the most loyal geographical electoral base for both major pro-democracy market-oriented political parties: Yabloko and Russia's Choice/Union of Rightist Forces (SPS). Until the last electoral cycle the North Caucasian republics provided extensive support for the Communist Party of the Russian Federation (CPRF), significantly exceeding the total vote for this party nationwide: 38.6 percent and 13 percent respectively in 1993, 38.6 percent and 23.4 percent in 1995, 34.02 percent and 24.29 percent in 1999. In the 2003 electoral contest, North Caucasus gave 67.42 percent of the regional vote to United Russia, which was almost 30 percent higher than the national share awarded to this political party by the Russian electorate.

These cases, along with the East-West geographical cleavage in Ukraine, which will be discussed in detail later in this article, appear to provide empirical evidence supporting the argument that the territorial variable in conjunction with ethnic and historical factors may indeed have a profound influence on electoral behaviour. My discussion shows that some regions 'resist' the overall trend manifested in the five nations towards greater nationalization of their party systems.

Many studies of the Russian political geography emphasize significant regional variations in party strength and the heterogeneity of its national electoral map (Slider et al., 1994; Clem and Craumer, 1995a; 1995b; 2000; Orttung and Parrish, 1996; Hough, 1998). However, my findings demonstrate that at the first competitive elections after the break-up of the Soviet Union, the Russian Federation represented a more homogeneous pattern in terms of the regional-party support than did other case-studies. In fact, the average CV value at the founding election in Russia was a relatively low 0.556 for all 89 territorial units, and an even lower 0.343 for 15 super-regions, in comparison to 1.15 in Ukraine, 0.822 in Lithuania, 0.667 in Estonia, and 0.476 in Latvia.7 The second cycle of post-independence elections narrowed a gap between the Russian Federation and the other four nations. The latest electoral contest decreased the variability coefficients in Lithuania (0.307), Latvia (0.314), and Estonia (0.387) to or below the Russian level (CV-89= $0.485, \mathrm{CV}-15=0.364)$. In the past decade, the Baltic states experienced solid, positive dynamics towards nationalization of their party systems. Estonia, Latvia, and Lithuania, which exhibited a relatively high degree of geographical variation in party strength during the early 1990s, were able to achieve a significantly more uniform pattern of party support across their countries 10 years later. In the Russian Federation, which manifested the most homogeneous regional pattern of party strength among the five countries after the disintegration of the USSR, further 'nationalization of the Russian electorate' ( $O$ ' Loughlin et al., 1996: 382) occurs very slowly.

The nationalization of the Ukrainian political parties is lagging behind the four other former Soviet republics. Beginning with the first cycle of the post-independence elections, the Ukrainian party system consistently produces by far the least uniform spatial pattern of party support. It is a wellknown fact that leading political organizations in this nation are clearly split according to territorial lines. Their electoral strength is narrowly concentrated in several geographically close regions. Outside of such areas, the level of their support is significantly lower. The Communist Party of Ukraine (CPU) and most 'parties of power' dominate eastern and southern parts of the country. Western Ukraine and the Kyiv region are the electoral strongholds of centre-right, pro-democracy, and nationalist political formations (Table 5). For example, the winner of the 2002 elections, Our Ukraine, headed by Viktor Yushchenko, received 23.53 percent of the national vote. This electoral coalition achieved a landslide victory in Galicia: 74.61 percent of the vote in Ivano-Frankivs'k, 69.01 percent in Ternopil', and 63.92 percent in L'viv oblasts. At the same time, this organization failed to impress in the East, obtaining only a meagre share of the vote in Donets'k (2.69 percent) and Luhans'k (3.62 percent) regions. The CPU and the coalition For United Ukraine, which comprised five regional parties of power, demonstrated a completely opposite voting pattern. Their main support came from the two easternmost regions. The CPU received 39.68 percent of the vote in Luhans'k and 28.78 percent in Donets'k; For United Ukraine gained 14.38 percent and 36.83 percent correspondingly. Neither of these two organizations was able to obtain more than 4 percent of the vote in 
any of the three Galician oblasts. The 2002 elections were not an exception. Since this country achieved its independence, major Ukrainian political organizations have failed to appeal to and mobilize the electorate uniformly across the nation and remain dependent on their geographical support base.

There are some signs that the Ukrainian party system has a potential for greater political homogeneity. In their spatial analysis of the 1998 elections to the Rada, Melvin J. Hinich, Valeri Khmelko, and Peter C. Ordeshook reach the conclusion that the eastern and western parts of the Ukrainian electorate perceive things in similar ways and evaluate the alternatives that confront them using equivalent criteria. Preferences differ, but there remains a vast middle ground that can be nurtured in search of a national compromise, if not consensus' (Hinich et al., 1999: 182-3). My finding regarding the Ukrainian party system seems to agree with this argument. The latest Rada election produced the lowest CV value in Ukraine since its independence, indicating a trend to an increasingly uniform pattern of party support across this nation. However, the gap between Ukraine and the other four case-studies is still very significant, which may be detrimental to the process of institutionalization of the national party system and overall stability in this society.

\section{Political parties}

In addition to the overall downward tendency of the variability coefficient at the party-system level in the five countries, many individual political organizations also demonstrate a clear trend towards a more uniform dispersion of their regional support. With the exception of two Russian pro-democracy parties, Yabloko and Russia's Choice/Union of Rightist Forces, this observation is particularly valid in relation to those parties that contested at least three cycles of national elections, in most cases under their own names. For example, the CV value for three political parties that have dominated Estonian politics since its independence - the Isamaaliit, Reform Party, and Centre Party - dropped consistently over time. Thus, in the 1992 elections, the combined CV for Isamaaliit and the Estonian National Independence Party (ERSP), which merged before the next electoral cycle, was 0.453 . It steadily decreased to 0.315 in 2003 . Latvia's Way, which was part of every single government in post-1991 Latvia until 2002, and its major coalitional partner Fatherland and Freedom (TB), as well as the Lithuanian Democratic Labour Party (Brazauskas Social Democratic Coalition in 2000) demonstrate a similar pattern (Tables 1-3).8 In Russia, the CV value for the CPRF consistently decreased in all post-1991 elections (Table 4). One can assume that the more uniform support achieved by these political formations among voters nationwide over time was due to increased party name recognition and expansion of their regional organizational structures, key elements of political institutionalization.

The historical evidence suggests that a party system dominated by political organizations leaning towards the political centre is conducive to a successful democratic transition. Conversely, the centrifugal party system which features weak centre and powerful political formations of the far right and far left may contribute to a democratic breakdown. A positive development for the consolidation of democracy in Estonia, Latvia, and Lithuania is that centrist political parties consistently maintain relatively uniform regional strength in these nations, and parties with more extreme ideological beliefs do not. For example, the centre-right Homeland Union/Lithuanian Conservatives (TS/LK), Latvia's Way, Isamaaliit and Res Publica in Estonia, as well as the centre-left Estonian Centre Party and social-democratic organizations in Lithuania manifested the lowest levels of regional variability year after year. At the same time, political formations which adhere to more radical leftist or rightist ideas are not able to master uniform support across their nations and draw their strength from a much narrower regional base. For example, Young Lithuania, the Estonian Citizen coalition, or the hard-line Latvian Socialist Party exhibited the highest values of variability coefficient in their countries. The large number of moderate political parties which enjoy relatively even strength across voting districts is a healthy sign for political institutionalization of a democratic party system in a transitional nation.

Unfortunately for the Ukrainian and Russian democratic transitions, these two countries demonstrate a diametrically opposite pattern of party-system development. The party systems here are dominated by the radical leftist or rightist political forces on the one hand, and 'pragmatic' parties of power on the other hand. These organizations were able to maintain consistently the most uniform political support across the voting districts in both nations. The 2003 election to the Russian Duma is a telling example. The hard-line CPRF and the extremist Liberal Democratic Party of Russia produced the lowest CV values: 0.353 and 0.349 for 89 constituencies ( 0.272 and 0.319 for 15 territorial units) respectively. Only the Kremlinsponsored party of power, United Russia ( $C V-89=0.287$ and CV-15 $=0.237$ ), drawing on the power 
of the governmental apparatus and the ORT, which is the only TV station available in all Russian regions, fared better than the extreme left and right political forces. The LDPR, CPRF, and Unity/United Russia have performed very well in all other elections to the Russian legislature. Their electoral success is in part due to their ability to continually maintain relatively even regional electoral support in the nation.

The electoral strength of two main Russian reformist political organizations - Russia's Choice/Union of Rightist Forces and Yabloko - is geographically narrower than that of other major electoral contestants. These two parties 'found their largest constituencies in the Northwest, Urals, and in Moscow city and oblast' (Clem and Craumer, 2004: 244). In most post-independence elections, Yabloko and Russia's Choice/Union of Rightist Forces produced the highest values of their variability coefficients in comparison to other meaningful electoral contestants (Table 4). In fact, values of the variability coefficient of Russia's Choice/Union of Rightist Forces and Yabloko were higher in 2003 than 10 years earlier. For example, at the founding elections Russia's Choice/Union of Rightist Forces demonstrated the CV value 0.400 for 89 regions and 0.405 for 15 'super-regions'. At the latest electoral cycle in 2003, its variability coefficient increased to 0.579 (89 units) and 0.418 (15 units). Yabloko manifested the same pattern. Evidently, both political organizations have not been able to widen their electoral support base, have lost a significant share of their vote in Russian provinces, and have become increasingly dependent on a smaller number of administrative units within the Russian Federation. It became a particularly serious issue for these two centrist parties at the latest elections to the Duma in 2003, contributing to their failure to cross the 5 percent electoral threshold.

The weakening of a party's traditional support base and the failure to gain new ground proved a recipe for electoral disaster for the Russian reformist forces. It is also a matter of great concern for their counterparts in Ukraine. The inability of the major centre-right political organization, Our Ukraine, to penetrate the most populated eastern and southern parts of the country is likely to negatively affect the future development of this coalition, as well as the Ukrainian party system in general. Consistently, Rukh and later Our Ukraine, as well as the centreleft Socialist Party of Ukraine (SPU), exhibit the highest CVs in comparison to other political organizations. In the 2002 elections to the Rada, Our Ukraine and the SPU displayed the least uniform regional pattern of party support among major political organizations: 0.833 and 0.921 respectively (Table 5). Electoral strength of governmentsponsored For United Ukraine (CV = 0.671 ) and the United Social Democratic Party of Ukraine (CV = 0.604), as well as the hard-line CPU (CV = 0.636), was more evenly dispersed across the country.

\section{Conclusion}

The field of post-Soviet studies in political science suffers from a major shortcoming. Most of what we know about the politics in the former Soviet republics comes from one country, the Russian Federation. For example, in the last decade 85 percent of all publications in the leading academic journals on the topic of elections in post-Soviet nations represented exclusively single-country investigations of Russia. Joshua A. Tucker writes:

[I]t should raise some red flags. If the field continues to develop in this direction, then there is a realistic danger that much of what we learn about elections and voting in the post-communist context will be based on our understanding of only one country, and one that is hardly representative of the lot. (Tucker, 2002: 278)

Analysis of electoral geography in Estonia, Latvia, Lithuania, Russia, and Ukraine shows that party systems in the five nations reveal diverse patterns of political institutionalization. Although all five countries manifest a tendency towards a greater regional uniformity of party support, the pace of this trend is different in different nations. After three Baltic states restored their independence, geographical support for their major political parties was gradually becoming more homogeneous with every electoral cycle. The centre-leaning parties occupy key positions in the political system of the Baltic states and in comparison to more radical political forces enjoy relatively even electoral support across regions, which constitutes a positive tendency in the development and institutionalization of their party systems, as well as in democratic consolidation in general.

The pace of 'nationalization' of the Russian party system is visibly slower than in the other four casestudies. Reformist political parties in this country have a limited regional support base and so far lack an ability to expand their influence into new geographical ground, which eventually contributed to their fiasco 
in the 2003 Duma elections. Radical rightist and leftist political forces, as well as nonideological 'parties of power', demonstrate the most uniform electoral support and dominate the party system in the Russian Federation.

The Ukrainian party system combines features of both Baltic and Russian patterns of political development. On the one hand, Ukraine demonstrates a distinct and healthy trend towards a greater nationalization of its party system. The latest Rada elections produced the least heterogeneous national electoral map since Ukrainian independence. On the other hand, similarly to the Russian case, the CPU and a number of parties of power manifest the most even regional strength. Two most consistent prodemocracy formations, the centre-right Our Ukraine and centre-left SPU, show the highest values of their variability coefficients. In addition, all major political parties in Ukraine are clearly divided along regional lines. The difference between Ukraine and the other four countries in terms of the uniformity of regional party strength is very significant. A lack of broad geographical support for leading Ukrainian parties might be a serious obstacle on the road of this nation towards democracy, social stability, and perhaps territorial integrity. A little more than a decade has passed since the break-up of the USSR. The former Soviet republics, which recently were parts of one country with the same political, economic, and social conditions, 10 years later reveal different patterns of institutionalization of their party systems. Our knowledge of democratic transitions and consolidations would be greatly enhanced if social scientists were to devote adequate attention to problems of building democratic institutions and factors contributing to this process in all postcommunist societies.

\section{Acknowledgements}

I am grateful to John Agnew and three anonymous reviewers for their helpful comments and suggestions on an earlier version of this work. I thank Christopher Lockman, Dominic Randazzo, and Halyna Kokhan for research assistance.

Table 1 Estonia: Coefficient of Variability $(C V)$ of main political parties in post-independence elections

\begin{tabular}{lcccc}
\hline & \multicolumn{4}{c}{ Electoral cycle } \\
\cline { 2 - 5 } Political organization & 1992 & 1995 & 1999 & 2003 \\
\hline Isamaaliit & 0.313 & 0.413 & 0.345 & 0.315 \\
Secure Home/Coalition Party & 0.548 & & 0.512 & 0.275 \\
Popular Front/Estonian Centre Party & 0.378 & 0.344 & 0.226 & 0.407 \\
Moderates & 0.780 & 0.902 & 0.264 & \\
Estonian National Independence Party (ERSP) & 0.593 & & & \\
Independent Royalists & 0.733 & & & \\
Better Estonia/Estonian Citizen & 1.532 & 0.513 & & \\
Estonian Pensioners' Union & 0.460 & & & \\
Coalition Party and Rural Union & & 0.330 & 0.359 & \\
Estonian Reform Party & & 0.393 & 0.830 & 0.777 \\
Our Home Is Estonia/Estonian United People's Party & & 0.602 & 0.874 & 0.174 \\
Right Wingers & & & 0.387 \\
Estonian Country People's Party/People's Union & & & 0.520 & \\
Res Publika & & & & \\
$C V$ mean & 0.667 & 0.541 & & \\
\hline
\end{tabular}

Sources: Author's calculations based on data from the Estonian National Electoral Committee (www.vvk.ee) and the Project on Political Transformation and the Electoral Process in Post-Communist Europe, Department of Government, University of Essex (www.essex.ac.uk/elections). 
Table 2 Latvia: Coefficient of Variability $(\mathrm{CV})$ of main political parties in post-independence elections

\begin{tabular}{|c|c|c|c|c|}
\hline \multirow[b]{2}{*}{ Political organization } & \multicolumn{4}{|c|}{ Electoral cycle } \\
\hline & 1993 & 1995 & 1998 & 2002 \\
\hline Latvia's Way & 0.267 & 0.152 & 0.197 & 0.110 \\
\hline Latvian National Independence Movement (LNNK) & 0.518 & & & \\
\hline Concord for Latvia-Rebirth of Economy/National Harmony Party & 0.650 & 1.127 & 1.045 & \\
\hline Latvian Farmers' Union (LZS) & 0.302 & & & \\
\hline Equal Rights/Latvian Socialist Party & 1.115 & 0.836 & & \\
\hline Fatherland and Freedom (TB) & 0.464 & 0.470 & 0.413 & 0.162 \\
\hline Latvian Christian Democratic Union (LKDS) & 0.096 & & & \\
\hline Democratic Centre Party/Democratic Party 'Saimnieks' & 0.396 & 0.098 & & \\
\hline People's Movement for Latvia & & 0.344 & & \\
\hline Latvian Unity Party & & 0.295 & & \\
\hline United List of LZS, LKDS and Latgale Democratic Party & & 0.200 & & \\
\hline LNNK and Latvian Green Party & & 0.452 & & \\
\hline Coalition 'Labour and Justice'/Social Democratic Alliance & & 0.428 & 0.222 & \\
\hline People's Party & & & 0.379 & 0.435 \\
\hline New Party & & & 0.207 & \\
\hline New Era & & & & 0.329 \\
\hline For Human Rights in a United Latvia & & & & 0.791 \\
\hline First Party & & & & 0.299 \\
\hline Alliance of Greens and Farmers & & & & 0.258 \\
\hline Latvian Social Democratic Workers' Party & & & & 0.131 \\
\hline$C V$ mean & 0.476 & 0.440 & 0.410 & 0.314 \\
\hline
\end{tabular}

Sources: Author's calculations based on data from the Latvian Central Election Commission (web.cvk.lv) and the Project on Political Transformation and the Electoral Process in Post-Communist Europe, Department of Government, University of Essex (www.essex.ac.uk/elections).

Table 3 Lithuana: Coefficient of Variability $(\mathrm{CV})$ of main political parties in post-independence elections

\begin{tabular}{lcc}
\hline & & Electoral cycle \\
\cline { 2 - 3 } Political organization & 1992 & 1996 \\
\hline Lithuanian Democratic Labour Party & 0.258 & 0.280 \\
Sajudis & 0.381 & 0.350 \\
Lithuanian Christian Democratic Party & 0.555 & 0.348 \\
Lithuanian Social Democratic Party & 0.499 & 0.249 \\
Lithuanian Christian Democratic Union and Young Lithuania & 2.416 & 0.269 \\
Homeland Union/Lithuanian Conservatives & & 0.180 \\
Lithuanian Centre Union & & 0.331 \\
Young Lithuania & & 0.222 \\
Lithuanian Women's Party & & 0.470 \\
Lithuanian Christian Democratic Union & & 2.241 \\
Electoral Action of Lithuanian Poles & & \\
Brazauskas Social Democratic Coalition & & 0.336 \\
New Union (Social Liberals) & & 0.170 \\
Lithuanian Liberal Union & & 0.217 \\
Lithuanian Peasants' Party & & 0.286 \\
$C V$ mean & & 0.525 \\
\hline
\end{tabular}

Note: All post-independence Seimas elections in Lithuania were conducted according to a mixed proportional representation/majoritarian system. Since proportional representation constituency results for the 1992 elections are not available, Table 3 reports cumulative vote for individual candidates with party affiliation in single-member districts for this electoral cycle. The 1996 and 2000 electoral data represent proportional representation regional results. Sources: Author's calculations based on data from the Central Electoral Committee of the Republic of Lithuania (www.vrk.lt), the Seimas of the Republic of Lithuania (www3.lrs.lt), and the Project on Political Transformation and the Electoral Process in Post-Communist Europe, Department of Government, University of Essex (www.essex.ac.uk/elections). 
Table 4 Russia: Coefficient of Variability $(\mathrm{CV})$ of main political parties in post-independence elections

\begin{tabular}{|c|c|c|c|c|c|c|c|c|}
\hline \multirow[b]{3}{*}{ Political organization } & \multicolumn{8}{|c|}{ Electoral cycle } \\
\hline & \multicolumn{2}{|c|}{1993} & \multicolumn{2}{|c|}{1995} & \multicolumn{2}{|c|}{1999} & \multicolumn{2}{|c|}{2003} \\
\hline & $C V-89$ & $C V-15$ & $C V-89$ & $C V-15$ & $C V-89$ & $C V-15$ & $C V-89$ & $C V-15$ \\
\hline Liberal Democratic Party of Russia & 0.303 & 0.268 & 0.396 & 0.330 & 0.355 & 0.343 & 0.349 & 0.319 \\
\hline \multicolumn{9}{|l|}{ Russia's Choice/Democratic Russia's } \\
\hline Choice/Union of Rightist Forces & 0.400 & 0.405 & 0.745 & 0.692 & 0.479 & 0.360 & 0.579 & 0.418 \\
\hline \multicolumn{9}{|l|}{ Communist Party of the Russian } \\
\hline Federation & 0.591 & 0.585 & 0.446 & 0.351 & 0.357 & 0.288 & 0.353 & 0.272 \\
\hline Women of Russia & 0.324 & 0.275 & 0.404 & 0.344 & & & & \\
\hline Agrarian Party of Russia & 0.670 & 0.471 & 1.037 & 0.607 & & & 0.929 & 0.379 \\
\hline Yabloko & 0.473 & 0.326 & 0.577 & 0.487 & 0.490 & 0.396 & 0.470 & 0.455 \\
\hline Party of Russian Unity and Concord & 0.737 & 0.256 & & & & & & \\
\hline Democratic Party of Russia & 1.066 & 0.129 & & & & & & \\
\hline Democratic Reforms Movement & 0.440 & 0.368 & & & & & & \\
\hline Our Home Is Russia & & & 0.713 & 0.388 & & & & \\
\hline Communists-Working Russia & & & 0.393 & 0.233 & & & & \\
\hline Congress of Russian Communities & & & 0.542 & 0.353 & & & & \\
\hline Party of Workers' Self-management & & & 0.536 & 0.307 & & & & \\
\hline Unity & & & & & 0.337 & 0.235 & & \\
\hline Fatherland-All Russia & & & & & 1.108 & 0.754 & & \\
\hline United Russia & & & & & & & 0.287 & 0.237 \\
\hline Motherland & & & & & & & 0.440 & 0.384 \\
\hline Pensioners' Party/Party of Social Justice & & & & & & & 0.473 & 0.450 \\
\hline$C V$ mean & 0.556 & 0.343 & 0.579 & 0.409 & 0.521 & 0.396 & 0.485 & 0.364 \\
\hline
\end{tabular}

Sources: Author's calculations based on data from the Central Electoral Commission of the Russian Federation (www.cikrf.ru), Federal Assembly of the Russian Federation (www.duma.ru ), and the Project on Political Transformation and the Electoral Process in Post-Communist Europe, Department of Government, University of Essex (www.essex.ac.uk/elections). 
Table 5 Ukraine: Coefficient of Variability $(\mathrm{CV})$ of main political parties in post-independence elections

\begin{tabular}{|c|c|c|c|}
\hline \multirow[b]{2}{*}{ Political organization } & \multicolumn{3}{|c|}{ Electoral cycle } \\
\hline & 1994 & 1998 & 2002 \\
\hline Communist Party of Ukraine & 0.660 & 0.529 & 0.636 \\
\hline Rukh & 0.739 & 0.907 & \\
\hline Socialist Party of Political Ukraine & 0.886 & & 0.921 \\
\hline Agrarian Party of Ukraine & 1.078 & 0.757 & \\
\hline Ukrainian Republican Party & 1.079 & & \\
\hline Congress of Ukrainian Nationalists & 2.316 & & \\
\hline Democratic Party of Ukraine & 1.293 & & \\
\hline Socialist Party of Ukraine and Peasants' Party & & 0.812 & \\
\hline Green Party of Ukraine & & 0.291 & \\
\hline People's Democratic Party of Ukraine & & 0.398 & \\
\hline Hromada & & 1.822 & \\
\hline Progressive Socialist Party of Ukraine/Natalia Vitrenko Bloc & & 1.038 & 0.521 \\
\hline Social Democratic Party of Ukraine (United) & & 1.243 & 0.604 \\
\hline Party of Reforms and Order & & 0.838 & \\
\hline Working Ukraine & & 1.174 & \\
\hline Our Ukraine & & & 0.833 \\
\hline For United Ukraine & & & 0.671 \\
\hline Yulia Tymoshenko Bloc & & & 0.651 \\
\hline$C V$ mean & 1.150 & 0.892 & 0.691 \\
\hline
\end{tabular}

Notes: The 1994 Rada elections took place according to the double ballot absolute majority formula. Table 5 includes cumulative vote in single-member districts for individual candidates with party affiliation. The 1998 and 2002 electoral data represent proportional representation regional results. In the 1994 elections, all political parties combined obtained $33.52 \%$ of the total vote with independent candidates receiving $66.48 \%$ (www.essex.ac.uk/elections). The 1994 results reported in Table 5 are calculated on the basis of the total national vote cast only for candidates nominated by political parties because the inclusion of the independent vote artificially decreases the $C V$ value. The inclusion of the independents in the calculations produces $C V \mu=0.93$ also preserving the consistent trend of the Ukrainian system of political parties towards greater nationalization over time.

Sources: Author's calculations based on data from the Central Electoral Commission of Ukraine (www.cvk.gov.ua), Verkhovna Rada of Ukraine (www.rada.gov.ua), the Project on Political Transformation and the Electoral Process in Post-Communist Europe, Department of Government, University of Essex (www.essex.ac.uk/elections), and the International Foundation for Election Systems, Archive of Ukrainian Elections: Full Election Results, Elections to the Verkhovna Rada of Ukraine. 


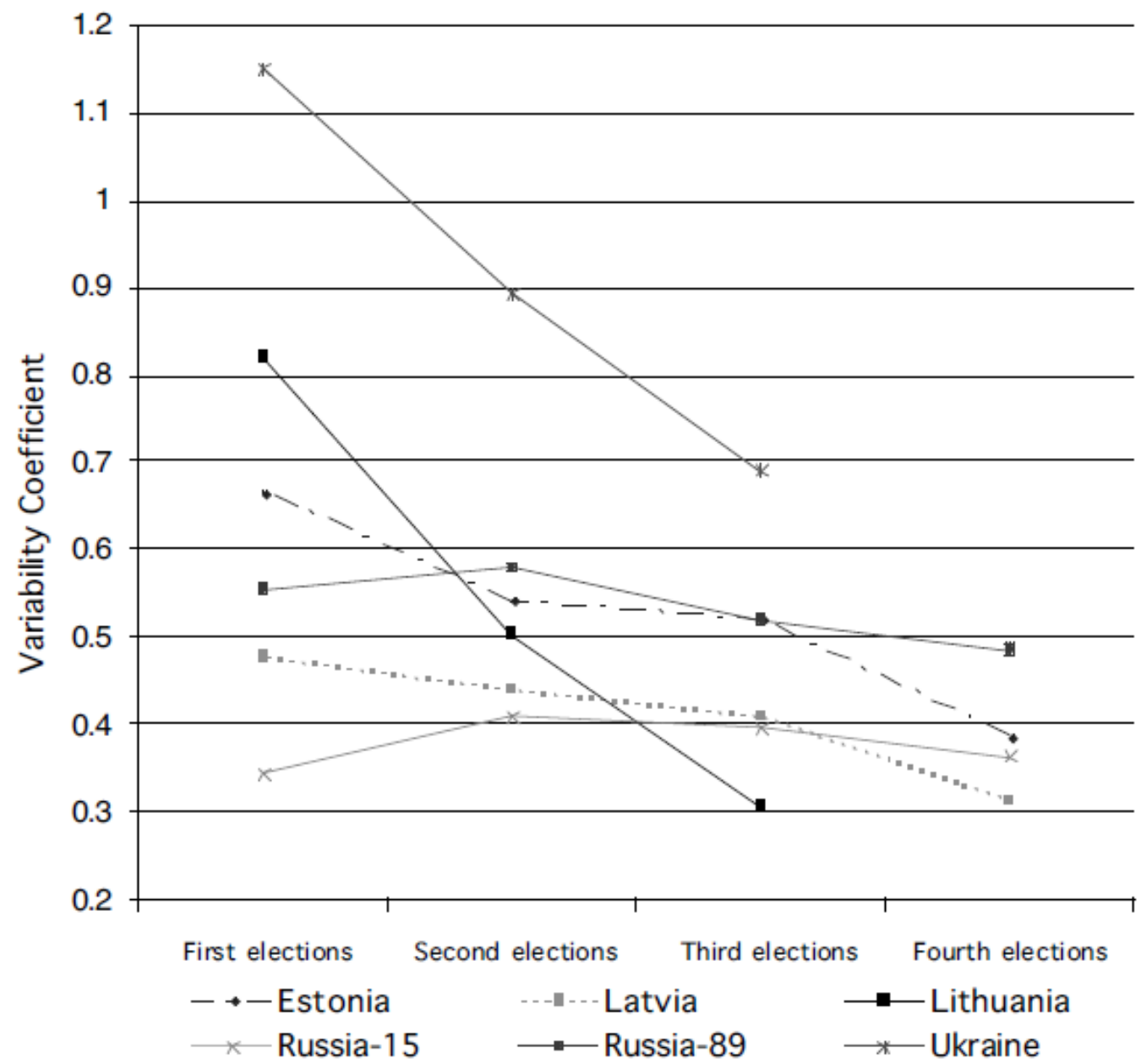

Figure 1 Variability coefficient of party systems $(C V \mu)$ in post-1991 elections in Estonia, Latvia, Lithuania, Russia, and Ukraine

Note: Values of Variability Coefficient are taken from Tables 1-5.

Notes

1 Although autonomy is an important element of political institutionalization, these two concepts should not be equated. For a detailed discussion of different dimensions of political institutionalization and relations between them, see Meleshevich (forthcoming).

2 For a theoretical discussion of the relationship between nationalization, development of party systems, and democratization, see Rokkan (1970) and Caramani (2004).

3 For a discussion of alternative measures of territorial homogeneity of electoral behaviour and party nationalization, see Allison (1978: 877); Lane and Ersson (1999: 114-17); Jones and Mainwaring (2003: 142-3); Caramani (2004: 58-63).

4 In their study of the nationalization of party systems in the Americas, Jones and Mainwaring (2003) encountered a similar problem comparing 50 territorial units (states) in the US and 7 provinces in Costa Rica. Their Gini-based index showed that the party system in Costa Rica (0.9) was more nationalized than the US party system (0.84). The authors considered the US as an 'intermediate nationalization country' and Costa Rica as a 'high nationalization country'. However, similarly to the CV, the Gini index is sensitive to the number of units: it produces a less nationalized pattern of a party system as the number of units increases. The more comparable number of units in the two countries would most likely result in changing their overall nationalization ranking.

5 The detailed tables which report both the CV and Standard Deviation results for each country as well as each geographical region individually within each country are available on the website of the National University of Kyiv-Mohyla Academy: [http://www.ukma.kiev.ua/eng_site/en/edu/under_gr/f_law/cv/dod/index.php]. 
6 The 1993 Duma elections took place shortly after the dismissal of the Russian national legislature which resulted in the October political crisis and the ban imposed on the Communist Party of the Russian Federation. Although the CPRF was allowed to participate in the contest, elections were conducted in a heavily controlled environment which prevented this party competing effectively with other electoral contenders. I must note that the CV scores of the CPRF and the LDPR, which attracted a large segment of the Communist Party's electorate, and, as a result, the mean $\mathrm{CV} \mu$ for this election, are somewhat artificial.

7 It would be appropriate to re-emphasize that the CV is biased towards the larger number of units producing a higher coefficient value.

8 Although Latvia's Way CV value was 0.110 in 2002 , this party failed to overcome the $5 \%$ electoral threshold and is not represented in the Eighth Saeima.

\section{References}

Agnew, J.A. (1988) "'Better Thieves Than Reds"? The Nationalization Thesis and the Possibility of a Geography of Italian Politics', Political Geography Quarterly 7 (4): 307-21.

Agnew, J.A. (1990) 'From Political Methodology to Geographical Social Theory? A Critical Review of Electoral Geography, 1960-87', in R.J. Johnston, F.M. Shelley and P.J. Taylor (eds) Developments in Electoral Geography, pp. 15-21. London: Routledge.

Agnew, J.A. (2002) Place and Politics in Modern Italy. Chicago, IL: University of Chicago Press.

Allison, P.D. (1978) 'Measures of Inequality', American Sociological Review 43 (6): 865-80.

Berglund, S. (1990) 'Introduction', in S. Berglund and S. Thomsen (eds) Modern Political Ecological Analysis. Åbo, Sweden: Åbo Akademis Förlag.

Bielasiak, J. (2002) 'The Institutionalization of Electoral and Party Systems in Postcommunist States', Comparative Politics 34 (2): 189-210.

Bungs, D. (1993) 'Moderates Win Parliamentary Elections in Latvia', RFE/RL Research Report, 9 July.

Caramani, D. (2004) The Nationalization of Politics: the Formation of National Electorates and Party Systems in Western Europe. Cambridge: Cambridge University Press.

Clem, R.S. and Craumer, P.R. (1995a) 'The Politics of Russia's Regions: a Geographical Analysis of the

Russian Election and Constitutional Plebiscite of December 1993', Post-Soviet Geography 36 (8): 459-

75.

Clem, R.S. and Craumer, P.R. (1995b) 'The Geography of the Russian 1995 Parliamentary Election: Continuity, Change, and Correlates', Post-Soviet Geography 36 (10): 586-616.

Clem, R.S. and Craumer, P.R. (2000) 'Regional Patterns of Political Preference in Russia: the December 1999 Duma Elections', Post-Soviet Geography and Economics 41 (1): 1-29.

Clem, R.S. and Craumer, P.R. (2004) 'Redrawing the Political Map of Russia: the Duma Election of December 2003', Eurasian Geography and Economics 45 (4): 241-61.

Diamond, L. and Linz, J.J. (1989) 'Introduction: Politics, Society, and Democracy in Latin America', in L. Diamond, J.J. Linz, and S.M. Lipset (eds) Democracy in Developing Countries: Latin America, pp. 1-58. Boulder, CO: Lynne Reinner.

Dix, R.H. (1992) 'Democratization and the Institutionalization of Latin American Political Parties', Comparative Political Studies 24 (4): 488-511.

Hinich, M.J., Khmelko, V. and Ordeshook, P.C. (1999) 'Ukraine's 1998 Parliamentary Elections: a Spatial Analysis', Post-Soviet Affairs 15 (2): 149-85.

Hopkin, J. (2003) 'Political Decentralization, Electoral Change and Party Organizational Adaptation', European Urban and Regional Studies 10 (3): 227-37.

Hough, J.F. (1998) 'The Political Geography of European Russia: Republics and Oblasts', Post-Soviet Geography and Economics 39 (2): 63-95.

Huntington, S.P. (1965) 'Political Development and Political Decay', World Politics XVII (3): 386-431.

Huntington, S.P. (1968) Political Order in Changing Societies. New Haven, CT: Yale University Press.

Janda, K. (1980) Political Parties: a Cross-national Survey. New York: Free Press.

Jin, Y. (1995) 'Testing Political Party Institutionalization: a Theory and Practice', Journal of Political and Military Sociology 23 (Summer): 43-63.

Jones, M.P. and Mainwaring, S. (2003) 'The Nationalization of Parties and Party Systems: an Empirical Measure and an Application to the Americas', Party Politics 9 (2): 139-66. 
Katz, R.S. (1987) 'Party Government and Its Alternatives', in R.S. Katz (ed.) Future of Party Government: Party Governments - European and American Experiences, pp. 1-26. Berlin: Walter de Gruyter.

Keohane, R. (1969) 'Institutionalization in the United Nations General Assembly', International Organization 23 (4): 859-96.

Lane, J-E., and Ersson, S.O. (1999) Politics and Society in Western Europe. London: Sage Publications. Levitsky, S. (1998) 'Institutionalization and Peronism,' Party Politics 4 (1): 77-92.

Lewis, P.G. (1994) 'Democratization and Party Development in Eastern Europe', Democratization 1 (3): 391-405.

Lutz, J.M. (1995) 'Diffusion of Voting Support: the Radical Party in Italy', in M. Eagles (ed.) Spatial and Contextual Models in Political Research, pp. 43-61. London: Taylor \& Francis.

McGuire, J.W. (1997) Peronism Without Peron: Unions, Parties, and Democracy in Argentina. Stanford, CA: Stanford University Press.

Mainwaring, S. and Scully, T.R. (1995) 'Introduction: Party Systems in Latin America', in S. Mainwaring and T.R. Scully (eds) Building Democratic Institutions: Party Systems in Latin America, pp. 1-34. Stanford, CA: Stanford University Press.

Meleshevich, A. (forthcoming) Party Systems in Post-Soviet Countries: a Comparative Study of Political Institutionalization in the Baltic States, Russia, and Ukraine. New York: Palgrave Macmillan.

O'Loughlin, J., Shin, M. and Talbot, P. (1996) 'Political Geographies and Cleavages in the Russian Parliamentary Elections', Post-Soviet Geography and Economics 37 (6): 355-85.

Openshaw, S. and Taylor, P.J. (1979) 'A Million or so Correlation Coefficients: Three Experiments on the Modifiable Areal Unit Problem', in N. Wrigley (ed.) Statistical Applications in the Spatial Sciences, pp. 127-44. London: Pion.

Orttung, R.W. and Parrish, S. (1996) 'Duma Votes Reflect North-South Divide', Transition 2 (4): $12-$ 14.

Panebianco, A. (1988) Political Parties: Organization and Power. Cambridge: Cambridge University Press.

Polsby, N. (1968) 'The Institutionalization of the US House of Representatives', APSR 62 (1): 144-68.

Randall, V. and Sväsand, L. (2002) 'Party Institutionalization in New Democracies', Party Politics 8 (1): 5-29.

Reynolds, D.R. (1990) 'Whither Electoral Geography', in R.J. Johnston, F.M. Shelley and P.J. Taylor (eds) Developments in Electoral Geography, pp. 22-35. London: Routledge.

Rokkan, S. (1970) Citizens, Elections, Parties. Oslo: Universitetsforlaget-McKay.

Slider, D., Gimpel'son, V. and Chugrov, S. (1994) 'Political Tendencies in Russia's Regions: Evidence from the 1993 Parliamentary Elections', Slavic Review 53 (3): 711-32.

Stepan, A. (2001) Arguing Comparative Politics. Oxford: Oxford University Press.

Tucker, J.A. (2002) 'The First Decade of Post-Communist Elections and Voting: What Have We Studied, and How Have We Studied It?', Annual Review of Political Science 5: 271-304.

van Biezen, I. (2003) Political Parties in New Democracies: Party Organization in Southern and EastCentral Europe. Houndmills: Palgrave Macmillan.

Welfling, M.B. (1973) Political Institutionalization: Comparative Analysis of African Party Systems. Beverly Hills, CA: Sage Publications.

Yule, G.U. and Kendall, M.G. (1950) An Introduction to the Theory of Statistics. London: Charles Griffin. 